\title{
PENGARUH STRATEGI PENYULUHAN DAN TINGKAT PENDIDIKAN TERHADAP KEPEDULIAN KESEHATAN LINGKUNGAN
}

\author{
SUKO PRATOMO \\ pratomossuko@yahoo.com \\ Program Studi Pendidikan Matematika, \\ Fakultas Teknik, Matematika dan Ilmu Pengetahuan Alam \\ Universitas Indraprasta PGRI (UNINDRA)
}

\begin{abstract}
The Objective of the research is to study the effect of the extension strategy, the educational level and the interaction effect of those two variables to concern on the environmental health. The research was conducted in Purwakarta Regency with a sample of 36 housewives by using an experiment with analysis technique was used ANAVA with 2 lines; $2 x 2$ factorial design, significantly $\alpha: 0,05$. Based on the results of these research are: 1) Basically we could find the influence towards the housewives concern on the environmental health of using the cooperative extension strategy and the presentation strategy. 2) The housewives who have high educational level more highly concern towards the environmental health than of those who received presentation. 3) The housewives who have low educational level and received presentation strategy more highly concern towards the environmental health than of those who received cooperative strategy. 4) There is an interaction between extension strategy and the educational level towards the housewives concern on the environmental health.
\end{abstract}

Keywords: The Effect Of The Extension Strategy, The Educational Level, and Environmental Health

\section{PENDAHULUAN}

Interaksi antara manusia dan lingkungan merupakan suatu proses alamiah yang menjadi dinamika kelangsungan hidup. Perkembangan peradaban manusia melalui buktibukti artifak dan teknologi yang dilandasi oleh kebudayaan dan filosofi berpikir-nya telah membentuk pola kehidupan yang saat ini terjadi. Salah satu fenomena penting pada interaksi antara manusia dan lingkungannya adalah dampak-dampak yang ditimbulkannya, baik yang merugikan unsur-unsur kehidupan manusia, maupun bagi kondisi daya dukung lingkungannya. Gejala ini mulai dirasakan sejak revolusi industri sekitar 2 abad yang lalu, setelah ditemukan beberapa kerusakan ling-kungan yang menjadi dilema kehidupan masyarakatnya karena pen-cemaran dari limbah industri.

Semenjak dicetuskan dalam konvensi Sustainble Development (Pembangunan Berkelanjutan), (Sunu, Pramudya, 2001:14), kerusakan lingkungan dapat diidentifikasi sebagai berikut: pertama Kerusakan alam karena pertanian (pembukaan lahan), kedua: Kerusakan lingkungan karena peternakan, ketiga: Pencemaran lingkungan karena industrialisasi, dan keempat: Pencemaran lingkungan karena pertambangan.

Tipe-tipe kerusakan lingkungan tersebut dapat terukur berdasarkan indikatorindikator yang dapat dirasa-kan pada kondisi masyarakatnya, khususnya pada masyarakat di wilayah yang menga-lami kerusakan. Antara lain menurunnya kualitas kesehatan manusia, tingkat kemiskinan, tingkat kesulitan sumber daya dalam mendukung kehidupan terutama makanan, dan kualitas hidup.

Dalam kaitan di atas, maka lingkungan hidup dapat didefinisikan sebagai jumlah total seluruh kondisi di dalam kehidupan organisme, dihasil-kan dari interaksi antara makhluk tidak hidup, komponen fisik dan kimia, dan dengan kehadiran parameter 
makhluk hidup berada. Sedangkan keterlibatan manusia dalam mempengaruhi kondisi lingkungan, seperti tertuang pada UU No.23 Tahun 1997 pada pengelolaan Lingkungan Hidup, yakni perilaku manusia sebagai bagian di dalamnya akan mempengaruhi kesatuan lingkungan hidup, karena lingkungan hidup adalah kesatuan ruang dan benda, daya, keadaan, dan manusia dengan perilakunya yang mem-pengaruhi kelangsungan peri kehidupan dan kesejahteraan manusia dan makhluk hidup lainnya (Soerjani, 2005: 15).

Sebagai makhluk hidup atau Homo faber yang mampu membuat alat, manusia dapat mengubah lingkungan alami menjadi bentuk lain yang diperlukannya misalnya mengubah lahan hutan menjadi areal pertanian, bandar udara, pelabuhan, kawasan industri, daerah persawahan dan sebagainya dalam waktu singkat.

Akibat peran dominan manusia yang disertai dengan bergesernya selera manusia yang semula hanya memanfaatkan sumber daya alam untuk memenuhi kebutuhan hidupnya menjadi untuk memenuhi keinginan hidupnya, maka kualitas lingkungan semakin menurun. Begitu juga dengan sungai, hutan, tanah, pegunungan fungsinya mengalami pergeseran yang menurunkan kualitasnya. Kondisi ini kemudian dikenal dengan istilah krisis lingkungan.

Seratus tahun yang lalu Indonesia masih memiliki hutan yang melimpah dimana pohon-pohonnya menutupi $80 \%$ sampai $95 \%$ dari total luas hutan. Tutupan hutan pada waktu itu diduga mencapai 170 juta hektar. Saat ini tutupan hutan jauh berkurang akibat kegiatan manusia. Indonesia kehilangan sekitar 17\% hutannya selama antara kurun 19851997. Diperkirakan laju rata-rata hutan yang rusak mencapai 1.7 hektar sampai 2 juta hektar pertahun (Anon; Sinar Bumi; 2006: 4).

Pada awalnya pertumbuhan populasi manusia berjalan sangat lambat. Sebagai ilustrasi Bumi memerlukan waktu satu abad dari tahun 1830 sampai dengan 1930 untuk melipat-gandakan jumlah penduduknya dari 1 milyar menjadi 2 milyar. Pada tahun 1970, jumlah penduduk dunia mencapai 3,7 milyar jiwa. Dua puluh lima tahun kemudian (1995) jumlah tersebut telah meningkat menjadi 5,7 milyar jiwa. Hal ini berarti terjadi penambahan penduduk sebanyak 2 milyar hanya dalam waktu 25 tahun. Berdasarkan kecenderungan tersebut, Badan Kependudukan Dunia mem-prediksi jumlah total penduduk dunia akan mencapai angka 9,8 milyar jiwa pada tahun 2050 (M. Soerjani, 2000:12). Mencermati besarnya pertumbuhan penduduk tersebut berarti pada tahun 2050, akan terjadi pertambahan penduduk sebanyak 4 milyar jiwa. Konsekuensi logis dari pertambahan itu adalah harus dipenuhinya kebutuhan akan tempat tinggal, sandang, pangan, fasilitas umum dan fasilitas sosial lainnya. Adanya pertambahan penduduk sebesar 4 milyar tersebut sudah pasti akan memberikan tekanan luar biasa terhadap sumber daya alam dan lingkungan. Akibat tekanan tersebut, maka akan terjadi kerusakan lingkungan yang menjurus kepada krisis lingkungan.

Kekhawatiran umat manusia pada lingkungan hidup akibat dari meningkatnya populasi penduduk dunia telah diramalkan oleh Malthus dengan postulatnya yang menyatakan bahwa kemampuan penduduk untuk bertambah secara kuantitas adalah lebih besar daripada kesanggupan sumber alam untuk menyediakan kebutuhan pangan manusia, sehingga secara matematis dapat dijelaskan bahwa pertumbuhan pangan mengikuti deret hitung sedangkan pertumbuhan penduduk mengikuti deret ukur (Meadows, Donella H, 1980:8-14).

Saat ini lingkungan global terus mengalami kerusakan. Hilangnya keanekaragaman hayati yang terus berlanjut, menipisnya persediaan ikan, meluasnya penggunaan lahan subur, memburuknya dampak perubahan iklim yang mengakibatkan sering terjadi bencana alam, dan semakin rentannya negara-negara berkembang serta semakin parahnya pencemaran udara, air dan laut telah merampas kehidupan layak dari jutaan orang (Deplu, 2002:2). 
Hasil penelitian yang dilakukan Kantor Menteri Negara Lingkungan Hidup tahun 2005 menunjukkan bahwa telah terjadi kondisi kritis pada beberapa sungai di Provinsi Jawa Barat, Jawa Tengah, Lampung, Pulau Lombok, serta Sumbawa (Kementerian Negara LH, 2005:3).

Dalam kehidupan, manusia membutuhkan adanya tumbuh-tumbuhan dan hewan yang sekaligus berfungsi sebagai sumber kehidupan. Dengan demikian tingkat kelayakan hidup manusia perlu perumusan yang lebih universal seperti yang pernah dicetuskan dalam KTT Bumi pada lingkungan hidup dan pembangunan pada tahun 1992 di Rio Janeiro, Brasil.

Salah satu permasalahan utama yang menjadi tolok ukur adalah aspek kesehatan manusia, yang di antaranya dapat menimbulkan, menciptakan, dan memelihara suatu lingkungan yang sehat bagi penghuninya (M. Soerjani, 2000:177).

Kesehatan lingkungan diartikan sebagai usaha sadar dan berencana untuk mengurangi dampak kegiatan terhadap kesehatan lingkungan sampai pada tingkat yang minimum dan untuk mendapatkan manfaatnya yang optimum dari lingkungan untuk mencapai kesejahteraan yang berkelanjutan (Otto, Soemarwoto, 2001: 85).

Menurut Barry Commoner paling sedikit ada enam penyebab dasar ancaman buatan manusia terhadap lingkungan, yaitu: 1) api; 2) mesin internal combustion; 3) timbal (lead); 4) fosfat dan nitrat; 5) deterjen, insektisida, pestisida, dan sebagainya; dan 6) tebaran radio-aktif (Commoner, Barry, 1970:118).

Hal ini nampak jelas bahwa akibat ekspansi semacam itu, suatu ketimpangan ekologis, seperti polusi udara, tanah, air gangguan fisiologis dan psikologis, polusi suara yang mengganggu konsentrasi mental menimbulkan bentuk-bentuk kepenatan dan penyakit baru.

Dalam upaya menciptakan kepedulian pada kesehatan lingkungan, terlebih dahulu harus didasarkan pada fakta bahwa masyarakat belum jelas atau belum mampu mengetahui bagaimana cara atau teknik dalam mengupayakan kesehatan lingkungan hidup yang dapat memberikan kontribusi bagi kehidupan penduduknya.

Indikator kesehatan keluarga selama ini seringkali dihubungkan dengan keberadaan ibu rumah tangga. Hal ini dikaitkan dengan aktifitasnya dalam mengatur dinamika keluarga termasuk kepedulian kesehatan ling-kungan. Kegiatan itu meliputi keaktifan kelompok ibu-ibu di dalam organisasi kemasyarakatan, peranan ibu dalam penanganan anggota keluarganya yang sakit termasuk pengaturan sanitasi rumah. Contoh kasus yang pernah muncul yakni di Desa Kembangkuning Kecamatan Jatiluhur Kabupaten Purwa-karta, di tahun 2007. Masyarakat Desa Kembangkuning terserang penyakit flek dan Infeksi Saluran Pernapasan Atas (ISPA) akibat limbah industri yang mencemari lingkungan. Lingkungan yang tercemar di antaranya daerah pertanian, sarana air bersih, dan polusi udara. Kasus tersebut baru terungkap oleh masyarakat di luar desa tersebut yang peduli terhadap lingkungan.

Dari kasus tersebut peneliti berasumsi bahwa terdapat beberapa hal yang menyebabkan suatu masyarakat desa tidak melakukan tindakan terhadap industri yang melakukan pencemaran lingkungan. Asumsi-asumsi tersebut di antaranya, pemerintah kurang melaku-kan sosialisasi dalam pengelolaan kesehatan lingkungan, pihak industri kurang memperhatikan ANDAS (Analisa Dampak Sosial), masyarakat kurang memiliki kemampuan atau kurang kepedulian pada wawasan kesehatan lingkungan, tingkat pendidikan masyarakat relatif rendah, sehingga masyarakat kurang berdaya dalam menangani masalah kesehatan lingkungan di desanya sendiri.

Dalam peningkatan kepedulian tersebut, kegiatan penyuluhan kepada kelompokkelompok masyarakat merupakan solusi yang strategis. Tetapi sangat dibutuhkan suatu strategi penyuluhan yang efektif dalam pelaksanaan tersebut. Karakteristik personal pada setiap individu di dalam masyarakat dalam menerima aspek pembelajaran melalui penyuluhan. Kemampuan personal secara kepribadian akan berbeda pada penyampaian aspek pembelajaran secara menyeluruh atau secara parsial. Hal ini di dalam buku Hall dan Lindzey diterangkan perbedaan 
psikologi seseorang dalam memperoleh pembelajaran baik secara organismik dan fenomenologis (Hall \& Lindzey, 1993:72).

Penyuluhan merupakan bentuk pembelajaran non-formal yang dapat dilakukan pada satuan masyarakat tertentu. Dengan menerapkan strategi penyuluhan sangat menetukan tingkat pencapaian pembelajarannya. Di lain pihak keberagaman personalitas ibu rumah tangga sangat heterogen dalam faktor usia, tingkat pendidikan, latar belakang sosial-budaya, status ekonomi, status kerumah-tanggaan, dan sebagai-nya. Oleh karena itu, penelitian ini diharapkan dapat menemukan solusi, bagaimana meningkatkan kepedulian masyarakat desa Kembangkuning terhadap kesehatan lingkungannya.

Untuk mengatasi rendahnya kepedulian masyarakat khususnya ibu-ibu pada kesehatan lingkungan tersebut, tentunya harus dicarikan solusi agar masalah tersebut dapat ditanggulangi minimal dikurangi dampaknya. Salah satu upaya untuk meningkatkan kepedulian ibu-ibu tersebut adalah melalui kegiatan penyuluhan lingkungan yang sesuai dengan rumusan Agenda 21 yang telah merekomendasikan pada pentingnya pendidikan penyadaran ibu-ibu pada lingkungan yang dilakukan oleh pemerintah melalui kampanye-kampanye yang bertujuan untuk meningkatkan kepedulian terhadap isu-isu lingkungan dan mempertimbangkan peran pendidikan formal maupun informal dalam setiap perencanaan dan kegiatan untuk mencapai pembangunan berkelanjutan yang berwawasan lingkungan. (KLH, 1995:5)

Dalam kenyataannya kegiatan penyuluhan kesehatan lingkungan yang diselenggarakan selama ini dijumpai berbagai kendala di antaranya: partisipasi ibu-ibu yang rendah untuk berperan dalam kegiatan penyuluhan yang disebabkan kurang-nya kepedulian terhadap permasalah-an yang ada, rendahnya komitmen ibu-ibu tersebut dalam menyelesaikan permasalahan lingkungan yang terjadi.

Kurang tercapainya sasaran peningkatan sumber daya manusia melalui penyuluhan disebabkan oleh; pertama metode penyuluhan kurang sesuai dengan kondisi sosial ekonomi masyarakat, kedua materi yang disampaikan tidak sesuai dengan kebutuhan masyarakat (Purwanto \& Subarna T, 2006:51). Selain itu materi dan metode pelaksanaan penyuluhan kesehatan lingkungan yang selama ini digunakan dirasakan belum memadai sehingga kepedulian masyarakat pada kesehatan lingkungan menjadi tidak utuh. Penggunaan materi dan penyuluh lingkungan yang tidak aplikatif menyebabkan penyelesaian masalah lingkungan hidup yang terjadi pada masing-masing daerah tidak dapat terlaksana dengan baik.

\section{TINJAUAN PUSTAKA}

\section{Kepedulian kesehatan lingkungan}

Perhatian akan lingkungan yang berkelanjutan mengisyaratkan agar manusia menyadari bahwa sistem kehidupan di bumi akan berada pada batas-batas terakhir kemampuan kita bersama (Chiras, Daniel,1988: 551). Selanjutnya akibat dari laju partumbuhan penduduk secara eksponensial maka diharapkan agar manusia mempedulikan masalah pelestarian yang sedang dihadapi oleh lingkungan hidup.

Kepedulian dapat didefinisikan memperhatikan, mengindahkan, meng-hiraukan pada suatu obyek, situasi, dan tujuan (Anon, http://www. hyperdictionary.com). Perhatian menurut Stern dan Bigot dalam Surya-subrata mempunyai dua definisi, yaitu: 1) Perhatian adalah pemusatan tenaga psikis yang ditujukan pada suatu obyek, dan 2) Perhatian juga merupakan banyak sedikitnya pandangan yang menyertai suatu kegiatan yang dilakukan (Sumadi, S, 1990: 14).

Selanjutnya menurut Kenneth E. Andersen dalam Jalaluddin Rahmat menyatakan bahwa perhatian adalah proses mental manakala stimuli menjadi menonjol pada saat stimuli lainnya melemah (Jalaluddin Rahmat, 1998: 52). Stimulus yang tidak sesuai atau 
bertentangan tidak dapat menjelaskan respons yang terjadi. Pemusatan persepsi itu disebut perhatian (Hilgard \& Akitson, 1979: 147).

Pencapaian kepedulian seperti diuraikan diatas, menunjukkan bahwa tingkat kepedulian ditentukan oleh besaran pengalaman dan keterkaitan emosional yang berasal dari proses belajar, baik secara formal, nonformal, maupun informal. Perhatian adalah kepedulian yang mendeskripsikan suatu perolehan dalam hasil yang dapat diukur dengan minat seperti yang dijelaskan oleh Lane dan Sears dalam Swan (JA, Swan:1973: 95)

Kepedulian pada lingkungan hidup begitu vital, namun bila tidak ditunjang oleh kepedulian dari seluruh komponen masyarakat maka tidak akan berarti merasakan masalah krisis lingkungan (Caldwell \& Niveson, 1992: 3). Hal ini dapat dikatakan sebagai perhatian dan sikap yang disadari oleh sistem nilai tentang suatu kondisi yang menuntut perilaku seseorang, apakah peduli dan mendukung pemeliharaan suatu kondisi tertentu atau bahkan kebalikannya. Manusia senantiasa dihadapkan dengan mekanisme mental yang mengevaluasi, membentuk pandangan, mewarnai perasaan, atau ikut menentukan kecenderungan perilakunya terhadap seseorang atau sesuatu yang sedang dihadapinya bahkan terhadap dirinya sendiri. (Anwar Saifuddin, 1995:3). Manusia tidak selalu bisa betul-betul obyektif dan bereaksi tanpa rasa suka dan tidak suka, senang dan tidak senang, atau peduli dan tidak peduli dari persepsi dan perilakunya.

Pendapat Chiras, Lingkungan adalah segala sesuatu yang ada di sekitar kita seperti udara, air, tanah, tumbuh-tumbuhan, hewan dan mikroorganisme. Lingkungan ini sebagai suatu sistem kompleks yang berada di luar individu yang mempengaqruhi pertumbuhan dan perkembangan organisme. Sedangkan Ilmu Lingkungan adalah suatu studi lingkungan baik komponen hidup dan tak hidup serta interaksi antara komponenkomponen tersebut (Chiras, 1991:3). Maka antara komponen-komponen dan lingkungan terjalin hubungan yang erat dan bersifat timbal balik yang saling mempengaruhi. Ada tiga (3) macam lingkunan hidup yaitu (1) Lingkungan Fisik (Physical Environment), (2) Lingkungan Biologis (Biological Environment), dan (3) Lingkungan Sosial (Social Environment).

Lingkungan Fisik adalah segala sesuatu di sekitar kita yang bersifat benda mati seperti gedung, cahaya, air dan sebagainya. Lingkungan Biologis adalah semua yang ada di sekitar kita yang bersifat organis seperti manusia, binatang, jasad renik, tumbuhan dan sebagainya, sedangkan Lingkungan Sosial terdiri atas manusia yang saling berinteraksi dengan sekitarnya. Jadi lingkungan meliputi semua makhluk (benda) yang ada di dalam suatu komunitas dan saling mempengaruhi.

Cone menegaskan bahwa kepedulian pada lingkungan adalah perhatian pada lingkungan yang dibagimenjadi 3 bagian utama yaitu; (1) Estetika lingkungan dan kualitas kehidupan, (2) Kesehatan lingkungan dan ketahanan manusia serta (3) Pengelolaan dan penggunaan secara efisien sumber daya alam (SDA) (John and Steven, 1984:26).

Menurut Odum, Ekosistem adalah suatu kesatuan unit organisme hidup (biotik) dan substansi tak hidup (abiotik) yang saling berinteraksi untuk menghasilkan suatu pertukaran materi antara komponen-komponen tersebut (Odum, 1997:3-8). Ada lima kecenderungan yang timbulkan dampak secara global yaitu: 1) industrialisasi yang semakin pesat; 2) pertumbuhan penduduk yang semakin padat; 3) kekurangan gizi yang semakin meningkat; 4) sumber alam yang tidak dapat diperbaharui sudah sangat berkurang; dan 5) lingkungan hidup yang makin rusak (D. Meadows, 1972:14).

Banyak penyebab kerusakan lingkungan dilakukan oleh tingkah polah manusia yang antroposentris. Antroposentris adalah teori lingkungan yang menyorot manusia dan kepentingannya dianggap yang paling menentukan dalam susunan ekosistem dan dalam kebijakan yang diambil dalam hubungannya dengan lingkungan alam secara langsung 
maupun tidak langsung. Dari sudut pandang antroposentris, alam hanya sebagai obyek yang digunakan untuk memuaskan kebutuhan manusia (Frederich and Petry Jr, 1990:277281). Kepedulian terhadap lingkungan seseorang meliputi keseimbangan hubungan antara manusia dengan lingkungan fisik. Secara teoritis kepedulian terhadap lingkungan mendasarkan pada tiga orientasi nilai yaitu nilai egoistic, humanistic, dan biospheric (Thomas, Stern, 1978:94).

Faktor penentu kepedulian terhadap lingkungan adalah faktor kepribadian dan sistem nilai. Diperlukannya manusia peduli terhadap lingkungan disebabkan (1) setiap individu merupakan bagian integral dari keseluruhan daur atau siklus lingkungan sehingga kelangsungan hidup dan kehidupannya mempengaruhi dan dipengaruhi oleh lingkungan sekitarnya, (2) Ketika mengelola sumber daya alam (SDA), manusia menjadi pelaku aktif yang bertindak sebagai pembina ekosistem, (3) setiap individu memiliki hak atas lingkungan yang baik dan sehat, serta berke-wajiban memelihara lingkungan hidup dan mencegah serta menanggulangi kerusakan dan pencemarannya.

Dipandang dari Ilmu Kesehatan, Kesehatan Lingkungan pada dasarnya adalah suatu kondisi atau keadaan lingkungan yang optimum sehingga berpengaruh positif terhadap terwujudnya status kesehatan yang optimum pula. Bahasan kesehatan lingkungan tersebut antara lain mencakup perumahan, penyediaan air bersih, pembuangan tinja dan sampah serta pembuangan air kotor (limbah), dan sebagainya (Soekidjo Notoatmodjo, 1997:147). Kesehatan lingkungan erat hubungannya dengan taraf sosial ekonomi, sehingga diperlukan hubungan lingkungan dengan manusia untuk merubah atau memperbaiki kualitas lingkungannya tergantung pada taraf sosial budayanya. Kesehatan lingkungan adalah hubungan timbal balik antara manusia dan lingkungan yang berdampak kepada derajat kesehatan manusia (Anwar, Azrul, 1990:8)

Kesehatan lingkungan merupakan aspek kesehatan masyarakat yang memperhatikan bentuk kehidupan dan kondisi sekeliling manusia yang menekankan pada pengawasan kesehatan terhadap berbagai faktor lingkungan. Menurut Badan Kesehatan Dunia (WHO) kesehatan lingkungan sebagai suatu ilmu dan keterampilan yang memfokuskan perhatiannya pada usaha pengendalian semua faktor yang ada pada lingkungan fisik manusia yang diprediksi akan menimbulkan hal-hal yang merugikan perkembangan fisiknya, kesehatannya maupun kelangsungan hidupnya.

Berdasarkan berbagai teori yang telah diuraikan, maka yang dimaksud dengan kepedulian tentang kesehatan lingkungan dalam penelitian ini adalah perhatian terhadap lingkungan, faktor kepribadian dan nilai-nilai lingkungan untuk meningkatkan dan memelihara kualitas lingkungan yang sehat berkaitan dengan pengelolaan sampah, kebersihan halaman, serta lingkungan fisik lainnya.

\section{Strategi Penyuluhan}

Strategi penyuluhan sebenarnya merupakan hakikat strategi pembe-lajaran yang dilakukan terhadap karak-teristik masyarakat. Strategi dapat diartikan suatu cara khusus dalam menterjemahkan strategi kerja yang didasarkan oleh suatu landasan atau pendekatan dalam memandang suatu permasalahan atau objek kajian. Menurut Semiawan cara pandang ini selanjutnya dijadikan penentuan dalam teknik dan cara dalam belajar mengajar agar tujuan instruksional dapat tercapai secara maksimal (Semiawan, Conny R. dan Joni, Raka T., 1993:54-55).

Istilah strategi (strategy) berasal dari kata benda dan kata kerja dalam bahasa Yunani. Sebagai kata benda, strategos merupakan gabungan kata "stratoa" (militer) dengan "ego" (memimpin). Sebagai kata kerja, stratego berati merencanakan (to plan).

Strategi dapat dibedakan dalam dua ciri yaitu ciri pertama, berhubungan dengan proses pembelajaran dan memfasilitasi pembelajar untuk belajar. Ciri kedua, berkaitan 
dengan tata cara khusus pelaksanaan metodologi yang mendasari penentuan desain sistem pembelajaran (Davis, Robert H., Alexander, Lawrence R., Youm Stephen L, 1974: 19). Berdasarkan teoretis tersebut, maka strategi adalah suatu cara dan kiat khusus terhadap objek kajian yang mendasari proses dan sistem pelak-sanaannya.

Penyuluhan, secara harfiah, bersumber dari kata suluh yang berarti obor ataupun alat untuk menerangi keadaan yang gelap. Menurut Rogers dalam Nurudin, penyuluh adalah seseorang yang atas nama pemerintah atau lembaga penyuluhan berkewajiban untuk mempengaruhi proses pengambilan keputusan yang dilaku-kan oleh sasaran penyuluhan untuk mengadopsi inovasi (penemuan). (Nurudin: 2007:131), yang dimaksud penyuluhan adalah kegiatan memberi penerangan atau-pun penjelasan kepada mereka yang disuluhi, agar tidak lagi berada dalam kegelapan mengenai suatu masalah tertentu, hal ini menurut Zulkarimein. (Nasution, Zulkarimein, 1989:9).

Tabel 1. Perbedaan antara Penyuluhan, Penerangan dan Propaganda

\begin{tabular}{|c|c|}
\hline Penyuluhan & $\begin{array}{l}\text { a. Dilakukan secara kontinuitas } \\
\text { b. Merupakan kegiatan nyata untuk membantu peningkatan kegiatan } \\
\text { yang telah ada } \\
\text { c. Mendorong melakukan perbaikan sendiri dan secara bersama } \\
\text { d. Mengandung unsur pendidikan } \\
\text { e. Menimbulkan perubahan cara berpikir, cara kerja dan cara hidup }\end{array}$ \\
\hline Penerangan & $\begin{array}{l}\text { a. Dilakukan pada saat diperlukan } \\
\text { b. Kegiatan insidentil, sekedar memberitahukan } \\
\text { c. Bersifat penjelasan } \\
\text { d. Tidak kontinuitas } \\
\text { e. Tak mengenal bimbingan lanjutan dan pelayanan praktis }\end{array}$ \\
\hline Propaganda & $\begin{array}{l}\text { a. Dilakukan pada saat diperlukan } \\
\text { b. Kegiatan insidentil di tempat itu sekedar ada kesempatan } \\
\text { c. Bertujuan komersial untuk memperoleh pasaran } \\
\text { d. Tanpa bimbingan lanjutan } \\
\text { e. Kadang-kadang menjatuhkan lawan/kawan }\end{array}$ \\
\hline
\end{tabular}

Prinsip-prinsip dasar dalam pendidikan dapat diterapkan dalam kegiatan penyuluhan, termasuk tujuan yang ingin dicapai, sama seperti tujuan pendidikan yaitu terjadinya perubahan tingkah laku dari orang yang disuluh. Sebagai proses pendidikan, penyuluhan termasuk pendidikan non formal dan merupakan pendidikan orang dewasa (Totok Mardikanto, 1993:15-16). Kartasapoetra membedakan penyuluhan, penerangan dan propaganda seperti terlihat pada tabel berikut ini. (Kartasapoetra, 1988: 20). Penyuluhan juga memiliki kekhususan yang berbeda dengan komunikasi massa seperti terlihat pada tabel berikut ini (Leta Rafael Levis,1996: 16-17).

Tabel 2. Perbedaan antara Komunikasi Penyuluhan dan Komunikasi Massa

\begin{tabular}{|l|l|l|}
\hline \multicolumn{1}{|c|}{ Kriteria } & \multicolumn{1}{c|}{ Komunikasi Penyuluhan } & \multicolumn{1}{c|}{ Komunikasi Massa } \\
\hline \hline Masalah & Sedang dihadapi masyarakat & Tidak tentu \\
\hline Strategi & Strategi Khusus & Tidak tentu \\
\hline Tujuan & Adopsi Inovasi & Membentuk opini \\
\hline Sasaran & Masyarakat tertentu & Masyarakat umum \\
\hline Isi/ Materi & Bersifat inovatif & Tidak hanya inovatif \\
\hline Tujuan Akhir & Adopsi dan perubahan perilaku & Perubahan perilaku \\
\hline Waktu & Sesuai masalah / kebutuhan & Kapan saja \\
\hline
\end{tabular}


Pengertian lain dari penyuluhan adalah suatu sistem pendidikan non-formal untuk masyarakat serta keluarganya, agar memperoleh kepedulian serta keterampilan lebih baik, dapat mengembangkan sikap positif terhadap perubahan, dan menumbuhkan kepercayaan terhadap kemampuan sendiri untuk melakukan usahanya (Anon, 1994: 201)

Strategi penyuluhan berdasarkan optimalisasi tingkat pemahaman yang dapat tercapai pada pembelajar didasarkan pada pola penyampaian materi dan sifatnya, yakni pem-belajaran aktif dan pembelajaran pasif. Berdasarkan sifat tersebut maka secara teknis khusus dalam optimalisasi pembelajaran dapat dibedakan antara strategi penyuluhan kooperatif dan ceramah. Penyuluhan secara kooperatif dan ceramah, akan memberikan kesempatan pada peserta belajar memiliki banyak kesempatan untuk menghayati, mengadakan pe-nyelidikan dan percobaan, mengum-pulkan bahan dari berbagai sumber, baik intra maupun antar bidang kajian, menganalisis problema-problema, mencari jawaban atas masalah itu dan kemudian menyimpulkannya. (Hamalik, Oemar, 1998: 125).

\section{Strategi Penyuluhan Kooperatif}

Penyuluhan kooperatif mengandung pengertian bekerja bersama dalam mencapai tujuan bersama. Dalam kegiatan kooperatif, peserta didik secara individual mencari hasil yang menguntungkan bagi seluruh anggota kelompoknya. Jadi, belajar kooperatif adalah pemanfaatan kelompok kecil dalam pengajaran yang memungkinkan peserta didik bekerja bersama untuk memaksimalkan belajar mereka dan belajar anggota lainnya dalam kelompok tersebut (Brenda, Dorn Conrad, 1988:12).

Sehubungan dengan pengertian tersebut, Slavin mengatakan bahwa strategi Penyuluhan kooperatif adalah suatu strategi Penyuluhan dimana peserta didik belajar dan bekerja dalam kelompok-kelompok secara kolaboratif yang anggotanya terdiri dari 4 sampai 6 orang, dengan struktur kelompoknya yang bersifat heterogen. Selanjutnya dikatakan pula, keber-hasilan belajar dari kelompok tergantung pada kemampuan dan aktivitas anggota kelompok, baik secara individual, maupun secara kelompok (Slavin, Robert E., 1983:87).

Pada dasarnya, strategi kooperatif mengandung pengertian sebagai suatu sikap atau perilaku bersama dalam bekerja atau membantu di antara sesama dalam struktur kerjasama yang teratur dalam kelompok, yang terdiri dari dua orang atau lebih dimana keberhasilan kerja sangat dipengaruhi oleh keterlibatan dari setiap anggota kelompok itu sendiri.

Cooperative learning juga dapat diartikan sebagai suatu struktur tugas bersama dalam suasana kebersamaan di antara sesama anggota kelompok. Strategi kooperatif lebih dari sekedar belajar kelompok atau kelompok kerja, karena belajar dalam model cooperative learning harus ada "struktur dorongan dan tugas yang bersifat kooperatif", sehingga memung-kinkan terjadinya interaksi secara terbuka dan berhubungan yang bersifat interdependensi yang efektif di antara anggota kelompok (Robert J. Stahl, 1994: 125)

Stahl mengatakan bahwa strategi Penyuluhan kooperatif menempatkan peserta didik sebagai bagian dari suatu sistem kerja sama dalam mencapai suatu hasil yang optimal dalam belajar. Strategi Penyuluhan ini berangkat dari asumsi mendasar dalam kehidupan masyarakat yaitu "getting better together", atau raihlah yang lebih baik secara bersama-sama (Stahl, Robert J. and Van Sickle, Ronald L., 1994: 18)

Aplikasinya di dalam penyuluhan di kelas, strategi penyuluhan ini mengetengahkan realita kehidupan masyarakat yang dirasakan dan dialami oleh peserta didik dalam kesehariannya dalam bentuk yang disederhanakan dalam kehidupan kelas. Strategi Penyuluhan ini memandang bahwa keberhasilan dalam belajar bukan semata-mata harus 
diperoleh dari guru, melainkan bisa juga dari pihak lain yang terlibat dalam penyuluhan itu, yaitu teman sebaya.

Langkah-langkah dalam penggunaan strategi Penyuluhan kooperatif secara umum dapat dijelaskan secara operasional sebagai berikut :

a. Langkah pertama yang dilakukan oleh guru adalah merancang rencana program Penyuluhan.

b. Dalam aplikasi Penyuluhannya di kelas, guru merancang lembar observasi yang akan digunakan untuk mengobservasi kegiatan peserta didik dalam belajar secara bersama dalam kelompok-kelompok kecil.

c. Langkah ketiga, dalam melakukan observasi terhadap kegiatan peserta didik, guru mengarahkan dan membimbing peserta didik baik secara individual maupun kelompok baik dalam memahami materi maupun mengenai sikap dan perilaku peserta didik selama kegiatan belajarnya.

d. Langkah keempat, guru memberikan kesempatan kepada peserta didik dari masingmasing kelompok untuk mempresentasikan hasil kerjanya. Dalam melakukan refleksi diri ini, guru tetap sebagai mediator dan moderator aktif. Artinya, pengembangan ide, saran dan kritik terhadap proses Penyuluhan harus diupayakan berasal dari peserta didik, kemudian barulah guru melakukan beberapa perbaikan dan pengarahan terhadap ide, saran dan kritik yang berkembang.

Hal penting yang perlu diperhatikan dalam meningkatkan efektifitas dan efisiensi Penyuluhan di samping keterlibatan secara aktif peserta didik, di dalam mengajarkan kepedulian, keterampilan, ataupun nilai-nilai adalah terciptanya hubungan baik antara guru dan peserta didik. Hubungan guru dan peserta didik dapat dikatakan baik apabila mempunyai; (1) keterbukaan yang memungkinkan terjalinnya keterus-terangan dan kejujuran, (2) penuh perhatian dimana masing-masing merasa dihargai, (3) saling ketergantungan dari masing-masing pihak, (4) keterpisahan yang memungkinkan berkembangnya keunikan (individualitas) masing-masing, dan (5) terpenuhinya kebutuhan besama sehingga tidak ada pihak yang merasa dikorbankan (Gordon, Thomas, 1997:23). Ini berarti bahwa strategi Penyuluhan harus lebih member-dayakan peserta didik, memandang peserta didik sebagai subyek yang aktif, sehingga perlu lebih memberikan kesempatan kepada peserta didik untuk bereksplorasi dan bereks-perimen dalam mengembangkan dirinya.

Berdasarkan uraian di atas dapat dikemukakan bahwa strategi Penyuluhan kooperatif mempunyai beberapa kelebihan, yaitu bahwa ; (1) peserta didik lebih memperoleh kesempatan dalam hal meningkatkan hubungan kerjasama antara teman, (2) peserta didik lebih memperoleh kesempatan untuk mengembangkan aktivitas, kreativitas, kemandirian, sikap kritis, sikap dan kemampuan berkomunikasi dengan orang lain, (3) guru tidak perlu mengajarkan seluruh kepedulian kepada peserta didik, cukup konsepkonsep pokok karena dengan belajar secara kooperatif peserta didik dapat melengkapi sendiri. Sedangkan sisi lemahnya adalah bahwa strategi Pe-nyuluhan kooperatif; (1) memerlukan alokasi waktu yang relatif lebih banyak, terutama kalau belum terbiasa, (2) membutuhkan persiapan yang lebih terprogram dan sistemik, (3) kalau peserta didik belum menguasai Penyuluhan kooperatif yang diper-lukan, pencapaian hasil belajar tidak maksimal.

\section{Strategi Penyuluhan Ceramah}

Strategi ceramah adalah cara penyampaian bahan ajar dengan komunitas secara lisan (K, Mertodihardjo, 1980: 2). Ceramah adalah suatu teknik penjelasan secara lisan yang dilengkapi dengan peng-gunaan alat bantu pandang dengar (audio visual) dan teknik-teknik atau kegiatan belajar lainnya seperti diskusi, simulasi dan penugasan. Lebih 
lanjut dikemukakan bahwa, ceramah akan lebih tepat digunakan apabila kegiatan Penyuluhan diawali dengan penyam-paian pokok-pokok informasi yang dapat merangsang para peserta untuk memberikan tanggapan dan pendapat serta untuk mengajukan pertanyaan. Strategi ceramah ini akan efektif digunakan apabila peserta telah termotivasi untuk memperoleh informasi.

Sebagaimana yang dikutip oleh Davies dari monograf tulisan Mc Leish yang berjudul "The lecture method" bahwa keberhasilan strategi ceramah tergantung kepada harapan peserta penyuluhan, kalau tersuluh menyukai ceramah maka akan ada faedahnya, kalau ia tidak menyukai ceramah maka hal itu akan gagal. Menurut Leish untuk mendapatkan hasil optimal maka ada beberapa situasi dan kondisi yang perlu untuk diperhatikan, yaitu: pertama, strategi ceramah cukup baik untuk mencapai tujuan kognitif tingkat rendah, dan efektif diterapkan pada jumlah peserta yang banyak. Kedua, strategi ceramah akan sukses dalam mencapai tujuan kognitif tingkat tinggi, apabila disajikan penemuan dan organisasi kepedulian yang baru. Ketiga, strategi ceramah baik untuk mencapai tujuan efektif, apabila ditangani secara trampil dan sensitif.

Beberapa alternatif untuk menyiasati penyuluhan dengan ceramah dapat dilakukan penyuluh dengan cara memodifikasi ceramah dengan strategi-strategi lainnya seperti strategi ceramah yang dapat dilakukan dengan cara: Pertama, memadukan strategi ceramah dengan strategi tanya jawab dan tugas. Kedua, strategi ceramah dengan diskusi dan tugas. Ketiga, memodifikasi strategi ceramah dengan strategi demonstrasi dan pelatihan (Syah, Muhibban, 2001: 203).

Beberapa kelemahan dari strategi ceramah adalah; Pertama, peserta terhalang untuk merespon secara langsung pada saat pokok-pokok informasi disampaikan. Kedua, waktu yang digunakan mungkin tidak cukup terutama apabila peserta sangat aktif dalam kegiatan melalui strategi lainnya. Ketiga, penyuluh harus menguasai pokok-pokok informasi dan sumber-sumber lain serta terlatih dalam menyampaikan materi dan upaya motivasi. Keempat, tidak semua jawaban dan penjelasan terhadap pertanyaan dan tanggapan para peserta didik dapat memuaskan setiap orang.

Ceramah akan tepat digunakan apabila kegiatan Penyuluhan perlu diawali dengan penyampaian pokok-pokok informasi yang dapat merangsang para peserta untuk memberikan tanggapan dan pendapat serta untuk mengajukan pertanyaan. Strategi ceramah ini akan efektif digunakan apabila peserta telah termotivasi untuk memperoleh informasi.

Uraian aspek Penyuluhan yang dilakukan dengan strategi ceramah yaitu menerangkan sambil menulis bagian-bagian yang penting di papan tulis. Proses belajar yang terjadi cenderung kepada belajar menerima atau reception learning, yaitu peserta menerima apa yang disajikan saja (Romiszowski, AJ, 1981: 280).

Strategi ceramah oleh Linden, yang dikutip dari pendapat Rosenshine, dapat disarankan dengan pendekatan Instructional Function, terutama dalam Penyuluhan formal, yaitu dengan mengikuti tahapan-tahapan Penyuluhan seperti; 1) melihat/memeriksa apakah peserta mengerjakan tugas rumah, 2) mempresentasikan materi, 3) mengerjakan latihan yang ada di buku (guided practise), 4) menjawab pertanyaan kalau ada yang menanyakan, 5) memberi tugas kembali.

Keberhasilan penggunaan stra-tegi ceramah bukan hanya terletak pada strategi itu sendiri, tetapi juga pada kemampuan seorang guru atau penyuluh dalam membuat strategi tersebut menarik sehingga mampu menyampaikan informasi atau kepe-dulian secara efektif dan tercapai sasaran, yang sering terjadi dalam penggunaan strategi ini adalah pelajaran disampaikan secara tidak baik (poorly presented), sangat jelek dalam pengorganisasian materi, ku-rang inspiratif, menjemukan sehingga membuat peserta didik menjadi tidak termotivasi (pasif). Untuk itu, strategi ceramah perlu direnca-nakan dengan 
baik sehingga mampu menarik perhatian peserta didik, jelas isi yang disampaikan, jelas tujuan yang ingin dicapai dengan materi tersebut, dan terorganisasi dengan baik (Anon, "Suggestion for effective Lecture", http://www1.umn.edu/ohr/teachlearn/ minncon/lecture1.html).

\section{Tingkat Pendidikan}

Dalam setiap masyarakat terdapat suatu tangga masyarakat, yaitu tingkatantingkatan sesuai dengan kedudukan, taraf ekonomi, keturunan dan sebagainya. Dalam masyarakat demokratis pun terdapat tangga masyarakat. Antara tingkatan yang satu dengan tingkatan yang lain terdapat perbedaan dalam sikap dan pandangan, baik terhadap kehidupan pada umumnya maupun terhadap tingkatan-tingkatan lainnya. Disamping itu tiap tingkatan memiliki kebanggaan terhadap angkatannya sendiri, dan mempunyai ciri dan corak kehidupan yang berlainan; terdapat perbedaan pola berfikir dan tingkah laku, perbedaan nilai, perbedaan tujuan dan harapan.

Perbedaan-perbedaan tersebut tercermin dalam visi dan kehidupan sehari-hari. Selanjutnya hal itu mempengaruhi pula sikap serta pola hidup peserta didik. Dibanding dengan lembaga sosial lain keluarga paling erat mengikatkan diri pada stratifikasi sosialnya. Havighurst mengemukakan, bahwa perbedaan-perbedaan tersebut dalam keluarga dapat terlihat pada "kebutuhan-kebutuhan dasarnya", "physical-settingnya", hubungan-hubungan antara sesama anggota keluarga, disiplin dan sebagainya. Apabila dibandingkan keluarga elite dengan keluarga jelata, nampak jelas perbedaan yang menyolok dalam hampir seluruh aspek kehidupannya, pakaian, tindak-tanduk, bahasa, keinginan dan harapan, kebutuhan dan harapan, jalan fikiran serta yang diminati, dan lain sebagainya. Tradisi dan corak kehidupan keluarga sehubungan dengan tingkatannya itu sejak semula dialami dan dihayati oleh setiap anggota keluarga. Bahkan keluarga secara sengaja dan langsung mengajarkan pola-pola kehidupan itu kepada anak, sehingga anak sejak kecil, langsung atau tidak langsung telah diperkenalkan dengan status sosialnya melalui keluarga tersebut.

Pendidikan dapat dibedakan menjadi tiga bagian yaitu pendidikan formal, pendidikan non formal dan pendidikan informal. Pendidikan formal adalah jalur pendidikan yang terstruktur dan berjenjang yang terdiri atas pendidikan dasar, pendidikan menengah dan pendidikan tinggi. Termasuk pendidikan nonformal adalah jalur pendidikan di luar jalur pendidikan formal yang dapat dilaksanakan secara terstruktur dan berjenjang. Sedangkan penddikan informal adalah pendidikan yang dilakukan keluarga dan lingkungan.

Direkomendasikan oleh Jim Cummis dalam Nasri, pentingnya program pendidikan nonformal di pedesaan dengan menggunakan bahasa ibu. Penggunaan bahasa ibu dalam pendidikan nonformal akan mengakibatkan pesan-pesan yang disampaikan menjadi lebih mudah dan cepat dihayat dan dimengerti oleh masyarakat. (Nasri, Program Pendi-dikan Nonformal untuk Masyrakat Pedesaan http://elearn.bpplps-reg.go .id). 


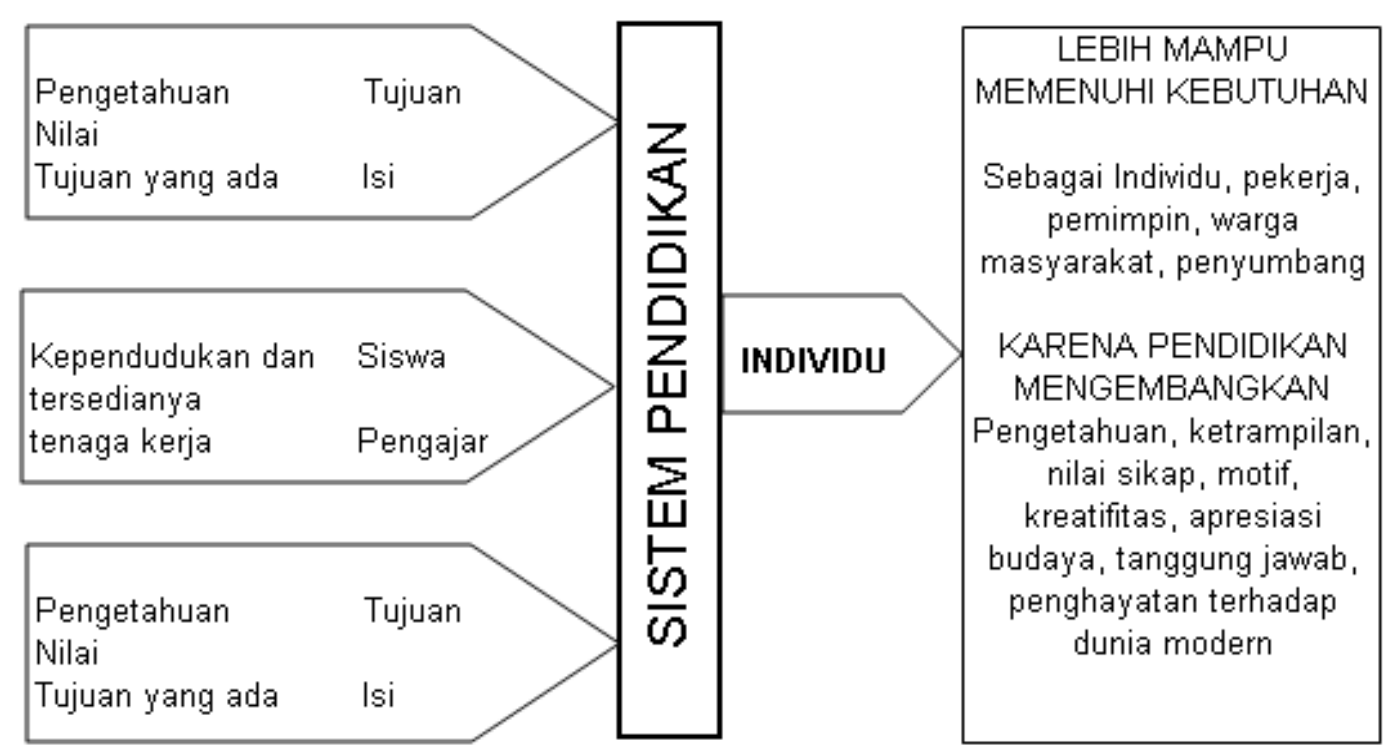

Gambar 1. Diagram Komponen Pokok Sistem Pendidikan

Dengan memiliki pribadi yang dewasa sebagai hasil dari pendidikan, seseorang akan memiliki kemampuan yang tidak sama dengan kemampuan orang lain. Kemampuan yang dimiliki tersebut akan menjadi pedoman baginya untuk bertindak dalam mengatasi masalah yang terjadi dalam kehidupannya sehari-hari. Pendidikan dapat diselenggarakan oleh sekolah maupun luar sekolah. Pendidikan sekolah sering disebut sebagai pendidikan formal karena diperlukan persyaratan dan hirarki tertentu se-belum seseorang masuk ke dalam-nya. Jalur pendidikan formal meliputi jenjang Sekolah Dasar, Sekolah Lanjutan yang terdiri dari Sekolah Lanjutan Tingkat Pertama dan Sekolah Lanjutan Tingkat Atas dan yang terakhir adalah Perguruan Tinggi. Seseorang yang mengikuti jalur pendidikan formal di sekolah akan memperoleh: (1) suatu kepedulian mengenai lingkungan sekitarnya, (2) kontrol (pengendalian) gerak yang cukup untuk memenuhi kebutuhankebutuhan pribadinya, (3) keterampilan-keterampilan bahasa sehingga memungkinkan baginya mengikuti percakapan-percakapan yang sederhana, (4) suatu pengertian antara pribadi dan kelompok (Crow, L. dan Crow, A., 1989: 6-7). Lamanya seseorang menempuh jalur pendidikan formal (dihitung dalam jumlah tahun) dapat digunakan sebagai indikator tingkat pendidikan yang dimiliki seseorang (Good, Thomas L. dan Brophy, Jere E., 1990:584).

Tingkat pendidikan berkaitan dengan jenjang pendidikan yang pernah ditempuh oleh seseorang yang berkesinambungan antara satu jenjang dengan jenjang lainnya yang terdiri atas jenjang pendidikan pra sekolah, pendidikan dasar, pendidikan menengah dan pendidikan tinggi (Soedijarto, 2000: 91-93). Fungsi pendidikan yang dikemukakan di atas sesuai dengan Theory of Educational Efect, bahwa pendidikan formal yang berlangsung di sekolah tidak saja mengajarkan siswa dengan membaca dan menulis, tetapi lebih jauh dari itu merupakan tempat berlangsungnya proses sosialisasi nilai-nilai, sikap dan perilaku yang relevan dalam kehidupan masyarakat. Oleh sebab itu seseorang yang lebih lama mengalami pendidikan di sekolah lebih terbuka terhadap ide-ide baru dan 
pengalaman baru lebih menghargai ilmu dan siap menerima perubahan (Inkeles, Alex dan Smith, David H., 1978:139-143).

Dalam pendidikan terdapat beberapa komponen pokok seperti terdapat pada Gambar 1. UNESCO mengembangkan konsep baru pendidikan yang berusaha menyatukan seluruh kegiatan baik yang terjadi di dalam sekolah maupun kegiatan pendidikan yang terjadi di luar sekolah seperti dalam masyarakat luas, dalam keluarga secara terpadu dan berlangsung sepanjang hidup manusia. Konsep UNESCO tersebut berdasarkan argumen bahwa semua kebudayaan itu beragam dan latihan dalam kelompok secara beragam berdasarkan berbagai macam faktor seperti gender, agama, kelas, dan lokasi geografi lebih diutamakan. Ini adalah implikasi dimana kegiatan pendidikan harus berpikir tentang pentingnya pendidikan multi budaya (Gonzalez, Norma, Moll Luis C. dan Amanti, Cathy, 2005: 131).

Karakteristik warga belajar orang dewasa adalah: (1) orang dewasa mempunyai pengalaman yang berbeda-beda, (2) lebih suka menerima saran-saran daripada digurui, (3) lebih perhatian pada hal-hal yang menarik bagi dia dan menjadi kebutuhannya, (4) orang dewasa yang pernah mengalami putus sekolah, mempunyai kecenderungan untuk menilai lebih rendah kemampuan belajarnya, (5) menyenangi hal-hal yang praktis, dan (6) membutuhkan waktu lebih lama untuk dapat akrab dan menjalin hubungan dekat dengan teman baru. (Andragogi. http://re-searchengines.com/0306supriadi.html.2006: 3).

Indikator keberhasilan pada proses pendidikan adalah hasil belajar. Indikator tersebut menekankan pada unsur kepedulian yang dapat diwujudkan melalui suatu proses/ strategi yang akomodatif dengan mempertimbangkan berbagai dimensi, terutama karakteristik peserta belajar yang belajar. Dalam kaitan ini di kemukakan Israel Scheffer, yaitu "Ada tiga relevansi yang berhubungan dengan karakteristik dan kualitas proses belajar mengajar atau pembinaan, yaitu:

a) Relevansi epistemologis, yakni berhubungan dengan bentuk komunikasi antara peserta didik dengan objek yang dipelajarinya, dalam relevansi ini kepedulian yang diperoleh peserta didik seharusnya tidak melalui pemberian informasi secara pasif melainkan harus ditempuh melalui proses bagaimana kepedulian itu diperoleh (learning how to learn) ;

b) Relevansi Psikologis, adalah merupakan kelanjutan dari dimensi yang pertama, namun relevansi psikologis ini tekanannya bukan lagi pada bentuk komunikasi, melainkan berhubungan dengan jenis dan aktivitas belajar. Relevansi ini mengutamakan kreativitas belajar yang dapat mengembangkan kemampuan berfikir dan meme-cahkan masalah;

c) Relevansi sosial dan moral, dimana hakikatnya relevansi ini merupakan konsekuensi logis dari relevan epistemologis dan psikologis. Hal ini sangat dimungkinkan mengingat hal sosialisasi akan mudah teraktu-alisasi manakala peserta didik memiliki kemampuan berpikir dan memecahkan masalah serta kemampuan dalam memroses perolehan kepedulian yang diharap-kannya. Diskusi antar peserta dalam memecahkan masalah, belajar menghargai pendapat orang lain, sikap toleransi dan kerjasama, adalah bentuk-bentuk nyata dari relevansi sosial (Israel Scheffer, 1971: 62).

Berdasarkan uraian di atas dapat disimpulkan bahwa tingkat pendidikan adalah jenjang dan lamanya seseorang mengalami pendidikan formal di sekolah sehingga mengalami relevansi epistemologi, psikologi

dan sosial moral. 


\section{METODE}

Penelitian ini dilakukan terhadap ibu rumah tangga di Desa Kembang-kuning Kecamatan Jatiluhur Kabupaten Purwakarta. Waktu yang dibutuhkan untuk penelitian ini adalah selama tiga bulan. Menurut data kesehatan Desa Kembangkuning menunjukkan sejarah perkembangan pada penyakit Hipertensi, ISPA (Infeksi Saluran Perna-fasan Atas) dan bronchitis. Sebagian besar penyakit-penyakit ini dijumpai pada anak-anak sampai usia 15 tahun. Oleh sebab itu, kaum ibu rumah tangga dalam mengemban kesejahteraan keluarga banyak yang terlibat di PKK tingkat desa, kegiatannya berorientasi pada kesehatan lingkungan, seperti, pengajian, posyandu, pekan kesehatan, kerajinan tangan.

Metode penelitian yang digunakan dalam penelitian ini adalah eksperimen.

Tabel 3. Desain Penelitian

\begin{tabular}{|c|c|c|c|}
\multicolumn{2}{|c|}{$\begin{array}{r}\text { Variabel } \\
\text { Perlakuan }\end{array}$} & \multicolumn{2}{|c|}{$\begin{array}{c}\text { Strategi Penyuluhan } \\
\text { Variabel Atribut }\end{array}$} \\
\cline { 2 - 4 } & $\begin{array}{c}\text { Kooperatif } \\
\text { A1 }\end{array}$ & $\begin{array}{c}\text { Ceramah } \\
\text { A2 }\end{array}$ \\
\hline $\begin{array}{c}\text { Tingkat } \\
\text { Pendi- } \\
\text { dikan } \\
\text { (B) }\end{array}$ & $\begin{array}{c}\text { Tinggi } \\
(\mathrm{B} 1)\end{array}$ & A1B1 & A2B1 \\
\cline { 2 - 4 } & $\begin{array}{c}\text { Rendah } \\
\text { (B1) }\end{array}$ & A1B2 & A2B2 \\
\hline
\end{tabular}

Keterangan:

Variabel Terikat $(\mathrm{Y}) \quad$ : Kepedulian tentang pemeliharaan kesehatan lingkungan

Unit Analisis : Ibu rumah tangga

Variabel Bebas

Perlakuan $\left(\mathrm{X}_{1}\right) \quad$ : Strategi dengan Penyuluhan

A1 : Kooperatif

A2 : Ceramah

Atribut $\left(\mathrm{X}_{2}\right) \quad$ : Tingkat pendidikan

B1: Pendidikan Tinggi

B2: Pendidikan Rendah

Unit analisis adalah Ibu rumah tangga di Desa Kembangkuning Kecamatan Jatiluhur Kabupaten Purwakarta. Teknik sampling menggunakan random sampling dengan sampel 36 orang. Dikelompokkan menjadi dua (2) kelompok untuk perlakuan penyuluhan strategi kooperatif, dan kelompok penyuluhan strategi ceramah. Masingmasing kelompok dilakukan pengukuran variabel atribut (tingkat pendidikan), kemudian ditentukan kelompok yang mempunyai Tingkat pendidikan yang lebih tinggi dan rendah.

Berdasarkan hasil pengumpulan data uji coba dan perhitungan validitas melalui perhitungan korelasi butir-butir (besaran $r$ ) dan dibandingkan dengan r-kritis (Product Moment), jika r-hitung < r-tabel, maka butir dinyatakan drop. Dari hasil perhitungan diketahui 2 butir soal drop, yaitu butir nomor 6 dan 24. Hal ini menjadikan jumlah butir yang layak untuk digunakan dalam menjaring data adalah sebanyak 22 butir soal.

Reliabilitas tes dari instrumen Kepedulian tentang kesehatan lingkungan dari hasil pemasukan dan perhitungan data dengan meng-gunakan rumus Alpha Cronbach sehingga dapat dikatakan mempunyai reliabilitas yang cukup. Reliabilitasnya terhadap butir-butir yang valid, diperoleh nilai 0,92. dengan angka ini dapat dinyatakan bahwa butir-butirnya mempunyai keterandalan tinggi. 


\section{HASIL dan PEMBAHASAN Deskripsi Data}

Dalam penelitian ini terdiri dari tiga variabel, masing-masing dua variabel bebas dan satu variabel terikat. Adapun variabel tersebut berturut-turut dengan deskripsi mengenai skor kepedulian kesehatan lingkunganyang diberikan strategi penyuluhan kooperatif dan strategi penyuluhan ceramah, skor kepedulian kesehatan lingkunganpada kelompok ibu rumah tangga yang mempunyai tingkat pendidikan tinggi, skor kepe-dulian kesehatan lingkunganpada kelompok ibu rumah tangga yang mempunyai tingkat pendidikan rendah, skor kepedulian kesehatan lingkungan pada kelompok ibu rumah tangga yang mempunyai tingkat pendidikan tinggi yang diberikan strategi penyuluhan kooperatif, skor kepedulian kesehatan lingkunganpada kelompok ibu rumah tangga yang mempunyai tingkat pendidikan rendah yang diberikan strategi penyuluhan kooperatif, skor kepedulian kesehatan lingkunganpada kelompok ibu rumah tangga yang mempunyai tingkat pendidikan tinggi yang diberikan strategi penyuluhan ceramah, dan skor kepedulian kesehatan lingkunganpada kelompok ibu rumah tangga yang mempunyai tingkat pendidikan rendah yang diberikan penyuluhan strategi ceramah.

Tabel 4. Hasil statistik deskriptif

\begin{tabular}{|c|c|c|c|c|}
\hline \multirow{2}{*}{$\begin{array}{c}\text { TINGKAT } \\
\text { PENDIDIKAN }\end{array}$} & \multirow{2}{*}{ Ket. } & \multicolumn{2}{|c|}{ STRATEGI PENYULUHAN } & \multirow[b]{2}{*}{ TOTAL } \\
\hline & & Kooperatif & Ceramah & \\
\hline \multirow{6}{*}{ 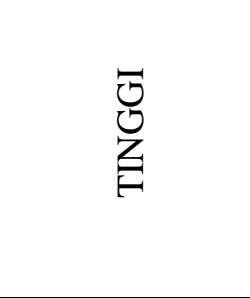 } & $\mathrm{n}=$ & 9 & 9 & 18 \\
\hline & $\Sigma=$ & 750 & 666 & 1,416 \\
\hline & $\overline{\mathrm{Y}}=$ & 83.33 & 74.00 & 78.67 \\
\hline & $\mathrm{Sd}=$ & 4.36 & 4.58 & 6.47 \\
\hline & Var $=$ & 19.00 & 21.00 & 41.88 \\
\hline & $\Sigma \mathrm{Y}^{2}=$ & 62,652 & 49,452 & 112,104 \\
\hline \multirow{6}{*}{ 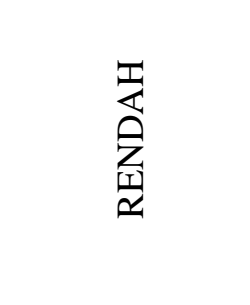 } & $\mathrm{n}=$ & 9 & 9 & 18 \\
\hline & $\Sigma=$ & 654 & 677 & 1,331 \\
\hline & $\overline{\bar{Y}}=$ & 72.67 & 75.22 & 73.94 \\
\hline & $\mathrm{Sd}=$ & 6.24 & 4.32 & 5.37 \\
\hline & Var $=$ & 39.00 & 18.69 & 28.88 \\
\hline & $\Sigma \mathrm{Y}^{2}=$ & 47,836 & 51,075 & 98,911 \\
\hline \multirow{6}{*}{ TOTAL } & $\mathrm{n}=$ & 18 & 18 & 36 \\
\hline & $\Sigma=$ & 1,404 & 1,343 & 2,747 \\
\hline & $\overline{\mathrm{Y}}=$ & 78.00 & 74.61 & 74.24 \\
\hline & $\mathrm{Sd}=$ & 7.58 & 4.37 & 14.01 \\
\hline & Var $=$ & 57.41 & 19.08 & 196.36 \\
\hline & $\Sigma \mathrm{Y}^{2}=$ & 110,488 & 100,527 & 211,015 \\
\hline
\end{tabular}

\section{Keterangan:}

n : Banyaknya sampel

Y : Data Kepedulian pada kesehatan lingkungan

Sd : Standar Deviasi (simpangan baku)

\section{Pengujian Hipotesis}

Untuk menguji hipotesis penelitian secara keseluruhan digu-nakan analisis varians (ANAVA) dua jalur pada taraf signifikansi 5\% $(\alpha=0.05)$. Kriteria pengujian 
adalah sebagai berikut: (1) jika untuk Antar Kolom nilai F hitung lebih besar daripada nilai $\mathrm{F}$ tabel $\left(\mathrm{F}_{- \text {hit }}>\mathrm{F}_{\text {-tab }}\right)$, dinyatakan terdapat perbedaan yang signifikan; (2) jika untuk Antar Baris nilai $\mathrm{F}$ hitung lebih besar dari pada nilai $\mathrm{F}$ tabel $\left(\mathrm{F}_{-h i t}>\mathrm{F}_{- \text {tab }}\right)$, dinyatakan terdapat perbedaan yang signifikan; dan (3) jika untuk Interaksi nilai $\mathrm{F}$ hitung lebih besar daripada nilai $\mathrm{F}$ tabel $\left(\mathrm{F}_{\text {-hit }}>\mathrm{F}_{\text {tab }}\right)$, dinyatakan terdapat perbedaan yang signifikan. Selanjutnya apabila diketa-hui terdapat interaksi maka dilanjutkan dengan uji Tukey untuk mengetahui efek interaksi (simpel effect) mana yang lebih tinggi.

Pada hipotesis kedua dan hipotesis ketiga, bahwa perbedaan yang sangat signifikan terhadap kepedulian ibu rumah tangga pada kesehatan lingkungan sangat dipengaruhi oleh tingkat pendidikan, pada kedua bentuk strategi penyuluhan tersebut. Ibu rumah tangga yang mempunyai pendidikan tinggi lebih baik perhatian dan minatnya terhadap kesehatan lingkungan dibandingkan ibu rumah tangga yang berpendidikan rendah apabila digunakan strategi penyuluhan kooperatif. Sedangkan pada strategi penyuluhan ceramah, ibu rumah tangga yang berpendidikan rendah yang lebih baik terhadap perhatian dan minat pada kesehatan lingkungan, dibandingkan ibu rumah tangga yang berpendidikan tinggi.

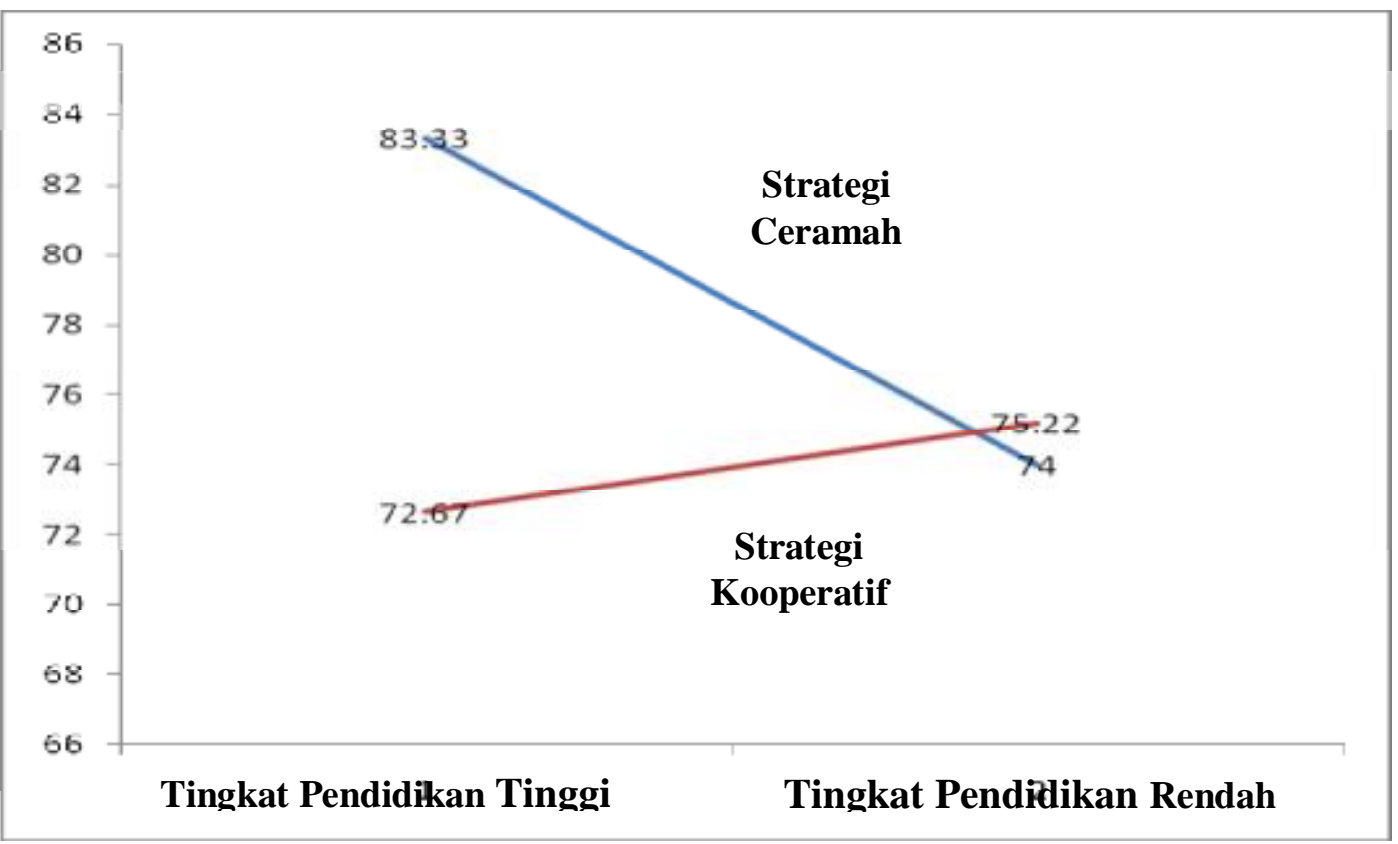

Gambar 2: Visualisasi Interaksi Strategi Penyuluhan dengan Tingkat pendidikan dalam Pengaruhnya terhadap Kepedulian pada kesehatan lingkungan

\section{PENUTUP}

\section{Kesimpulan}

Penelitian ini menggunakan metode eksperimen yang bertujuan untuk mengetahui perbedaan pengaruh strategi penyuluhan dan tingkat pendidikan terhadap kepedulian pada kesehatan lingkungan kepada ibu-ibu rumah tangga. Berdasarkan hasil pengujian hipotesis menunjukkan bahwa secara keseluruhan terdapat perbedaan kepedulian kesehatan lingkungan kepada ibu-ibu rumah tangga yang diberikan strategi penyuluhan kesehatan lingkungan secara kooperatif (A1) dan secara ceramah (A2). Selain itu terdapat pengaruh interaksi antara strategi penyuluhan dan tingkat pendidikan terhadap kepedulian pada kesehatan ling-kungan kepada ibu-ibu rumah tangga. Hasil temuan dalam penelitian ini adalah sebagai berikut: 
Pertama, penerapan strategi penyuluhan kooperatif memberikan kepedulian pada kesehatan lingkungan kepada ibu-ibu rumah tangga yang lebih baik dari pada penerapan strategi penyuluhan ceramah.

Kedua, pada kelompok Ibu-ibu rumah tangga yang mempunyai tingkat pendidikan tinggi, penerapan strategi penyuluhan kooperatif memberikan kepedulian kesehatan lingkungan ke-pada ibu-ibu rumah tangga yang lebih baik dari pada penerapan strategi penyuluhan ceramah.

Ketiga, pada kelompok Ibu-ibu rumah tangga yang mempunyai tingkat pendidikan rendah, penerapan strategi penyuluhan ceramah memberikan kepedulian pada kesehatan lingkung-an yang lebih baik dari pada penerapan strategi penyuluhan kooperatif.

Keempat, Terdapat interaksi antara strategi penyuluhan dengan tingkat pendidikan terhadap kepedulian pada kesehatan lingkungan kepada Ibu-ibu rumah tangga.

Berdasarkan uraian temuan di atas maka dapat disimpulkan bahwa dalam meningkatkan kepedulian ibu rumah tangga pada kesehatan lingkungan melalui penerapan strategi penyuluhan sebaiknya dapat diper-timbangkan tentang tingkat pendidikannya.

\section{Implikasi}

Rumusan implikasi dari hasil penelitian ini dapat diuraikan sebagai berikut:

Pertama, penerapan strategi penyuluhan secara kooperatif membutuhkan instruktur yang mema-hami betul dan berpengalaman dalam penyajian materi secara komprehensif, komunikatif, persuasif, dan melalui dinamika penyuluhan yang sesuai dengan karakteristik sosial budaya setempat. Untuk itu memerlukan lembaga pendidikan di masyarakat sesuai dengan dinamika masyarakat setempat. Hal ini berarti peran lembaga keswadayaan masyarakat yang bergerak dalam pendidikan akan ikut berkembang sesuai dengan kebutuhan masyarakat dan lingkungannya.

Kedua, keberhasilan pencapaian dalam membentuk kepedulian dalam kesehatan lingkungan bisa secara optimal juga dipengaruhi oleh faktor tingkat pendidikan para peserta penyuluhan. Oleh karena itu standarisasi pada aspek relevansi epistemologi, psikologi, dan sosial moral pada masing-masing tingkat pendidikan sangat dibutuhkan.

\section{Saran}

Berdasarkan kesimpulan dan implikasi pada bahasan sebelumnya, maka dapat disampaikan saran sebagai berikut:

Untuk Penyuluh, perlu memahami betul dan melibatkan ibu-ibu rumah tangga dalam penyuluhannya dengan penyajian materi secara komprehensif, komunikatif, persuasif, dan melalui dinamika penyuluhan tersebut ibu-ibu rumah tangga diharapkan akan memperoleh peningkatan kepedulian pada kesehatan lingkungan.

Untuk Kepala Desa, perlu penambahan wawasan melalui upaya pemberdayaan ibu-ibu rumah tangga dengan berbagai kegiatan antara lain kesadaran hukum (kadarkum), pembinaan, penyuluhan dan sebagainya, seperti dapat dilakukan dalam kelompokkelompok kecil, misalnya arisan.

Untuk Pemerintah Daerah, perlu pemantapan dalam strategi opera-sionalnya yaitu upaya strategi dan prioritas sasaran wilayah garapan mulai dari tingkat kecamatan sampai ke tingkat RT secara berjenjang dan pelaksanaan dalam kesehatan ling-kungan lebih ditingkatkan dengan adanya tim khusus atau kelompok yang melibatkan aparat Pemerintah Daerah dan tokoh masyarakat serta termasuk pihak swasta. 


\section{DAFTAR PUSTAKA}

2005. Information in Environment Occupation. World Health Organization.

Abdulhak, Ishak. 2000. Strategi Membangun Motivasi Dalam Pembelajaran Orang Dewasa. Bandung: Andira.

Anderson, Orin W., and David R. Krathwohl. 2001. A Taxonomy for Learning, Teaching, and Assessing. New York: Addison Wesley Longman, Inc. 2006. Andragogi. Sebuah Konsep Teoritik. http://re-searchengines. com/ 0306 supriadi. html.

Anon. Concern. http://www. Hyperdictionary.com

Benyamin S. Bloom. 1991. Taxonomy of Educational Objectives, Hand-book 1 Cognitive Domain. New York: Longman.

Brenda. Banan., Ritlan. An Action Learning Approach. http://chd. gse.gmu.edu/immersion/lao/fall2000/p/itforum.htm. 24 Oktober 2001

Chiras, Daniel D. 1988. Environmental Science: a Framework for Decision Making. California: The Benjamin/Cummings Publishing company, Inc.

Cunningham, William P., Mary Ann Cunningham dan Barbara Woodworth. 2005.

Enviromental Science A Global Concern. New York: McGraw Hill.

Dillon, Ann G. 2003. Making Connections Study Skills, Reading and Writing. United Kingdom: Thomson Wadsmorth.

Donaldson M. dalam Ishak Abdulhak. 2000. Strategi Membangun Motivasi Dalam Pembelajaran Orang Dewasa. Bandung: Andira.

Easton, Thomas A. dan Theodore D. Goldfarb. 2003. Taking Sides Clashing Views on Contro-versial Enviromental Issues. United States of America: McGraw Hill.

Enger, Eldon D. and Bradley F. Smith. 2004. Environmental Science. New York: McGraw-Hill.

Eugene P. Odum. 1997. Fundamental of Ecology. London: WB. Saunders Company.

Fraenkel, Jack R. dan Norman E. Wallen. 2003. How to Design and Evaluate Research in Education. Boston: McGraw-Hill Company.

Gonzales, Gonzalez, Luis C. Moll dan Cathy Amanti. 2005. Funds of Knowledge, Theorizing Practices in Households, Communities and Classrooms. New Jersey: Lawrence Erlbaum Associates.

Griffin, E. M. 2003. A First Look At Communication Theory. Boston, Mc Graw Hill.

Hall, Calvin S. \& Gardner Lindzey. 1993. Teori-teori Holistik (Organismikfenomenologis). Editor A. Supratiknya, Yogyakarta: Kanisius.

Iriantara, Yosal dan Yani Surachman. 2006. Public Relation Writing Pendekatan Teoritis dan Praktis. Bandung: Remaja Rosdakarya.

Israel Scheffer. 1971. Classroom Teaching Skiils. Washington DC: Heath and Company.

Jeanne H. Ballantine. 1993. The Sosiolgy Of Education; A Sistematic Analysis, third edition. New Jersey: Prentice Hall Inc.

John M. Palmer. 1995. Clasroom Teaching Skiils. Washington DC: Heath and Company.

Joice, B., M. Weil, dan B. Showers. 1991. Model of Teaching (Fourth Edition). Boston, M.A: Allyn and Bacon.

Joseph, Devito, A. 1997. Komunikasi Antar Manusia. Jakarta: Professional Books.

Kantor Menteri Negara Lingkungan Hidup. 2005. Status Lingkungan Hidup Indonesia 2005. Jakarta: Kantor Menteri Negara Lingkungan Hidup.

Keating, Michael. 1994. Bumi Lestari Menuju Abad 21 (terjemahan). Jakarta: Konphalindo. 
Langeveld, M. J. 1994. Menuju Ke Pemikiran Filsafat. (terjemahan). Jakarta: PT. Pembangunan.

Levis, Leta Rafael, 1996. Komunikasi Penyuluhan Pedesaan. Bandung: Citra Aditya Bakti.

Malik, Haris F. 2006. Perusakan lingkungan sumber permasalahan lingkungan Indonesia. Indonesian Journal for Sustainable Future, 2(3).

Marshall H. Segall, et al. 1999. Human Behavior In Global Perspective: An Introduction to Cross-Cultural Psychology, $2^{\text {nd }}$ edition. Boston: Allyn and Bacon.

Mathers, Dale. 2001. An Introduction to Meaning and Purpose in Analytical Psychology. Canada: Brunner Routledge.

Muhibban Syah. 2001. Psikologi Pendidikan; dengan pendekatan baru. Jakarta: Rosdakarya.

Mulyana, Deddy. 2001. Komunikasi Antar Budaya. Bandung: Remaja Rosdakarya.

Notoatmodjo, Soekidjo. 1997. Ilmu Kesehatan Masyarakat. Jakarta: Rineka Cipta.

Nurdu'a, M. Arief dan Nursyam B. Sudharsono. 1993. Hukum Lingkungan, Perundang-Undangan serta Berbagai Masalah Dalam Penegakannya. Bandung: Citra Aditya Bakti.

Nurgiyantoro, Burhan. 1995. Penilaian Dalam Pembelajaran. Yogyakarta: BPFE.

Nurudin. 2007. Sistem Komunikasi Indonesia. Jakarta: Raja Grafindo Persada.

Palmer, John M. 1995. Classroom Teaching Skills. Washington DC: Health and Company.

Pusposutarjo, Saprojo dan Sahid Susanto. 1993. Perspektif dari Pengembangan Manajemen Sumber Air dan Irigasi untuk Pembangunan Pertanian. Yogyakarta: Liberty.

Rejeki, Sri F. dan Anita Herawati. 1999. Dasar-dasar Komunikasi untuk Penyuluhan. Yogyakarta: Andi Offset.

Robert J. Stahl. 1994. Cooperative Learning in Social Studies: Hand Book for Teacher. USA: Kane Publishing Service.

Sadulloh, Uyoh. 2002. Filsafat Ilmu. Bandung: Rosda Karya.

Sarlito Wirawan. 1999. Psikologi Sosial, Individu Dan Teori-Teori Psikologi Sosial. Jakarta: Balai Pustaka.

Segall, Marshall H. et al. 1999. Human Behavior in Global Perspective: An Introduction to Cross-Cultural Psychology, 2nd edition. Boston: Allyn and Bacon.

Soekidjo Notoatmodjo. 1997. Ilmu Kesehatan Masyarakat. Jakarta: PT Rineka Cipta.

Soemarwoto, Otto. 2003. Analisis Mengenai Dampak Lingkungan. Yogjakarta: UGM Press.

Soerjani, M. 2005. Lingkungan hidup, pengelolaan dan pemanfaatan dalam pembangunan. Paper Pelatihan Amdal Komatsu 25 Februari 2005. Jakarta: Pelatihan Amdal Komatsu.

Sunu, Pramudya. 2001. Melindungi lingkungan dengan menerapkan ISO 14001. Jakarta: Grasindo.

Thomas, Gordon. 1997. Teacher Effectiveness Training. Terjemahan Aditya Kumara Dewi. Jakarta: Gramedia Pustaka Utama.

Van den Ban A.W. dan H.S. Hawkins. 1996. Agricultural Extension: second edition, Oxford: Blackwell Science.

WHO., 2005. Climate change and health. World Health Organization. www.who.int/en/, 2005 